\title{
Pengembangan Lembar Kerja Peserta Didik (LKPD) Matematika Untuk Siswa Tunarungu (SDLB-B)
}

\author{
Hedia Rizki ${ }^{1}$, Kamid $^{2}$, Saharuddin ${ }^{3}$ \\ ${ }^{1}$ Program Studi Magister Pendidikan Matematika, Universitas Jambi \\ Jalan Raden Mattaher No. 16,Jambi, Indonesia \\ ${ }^{2,3}$ Universitas Jambi, Jambi, Indonesia \\ hediasovia@yahoo.co.id
}

\begin{abstract}
This research is aimed at describing the development of students' worksheet of mathematic subject for deaf students and finding out the effectivity of mathematics worksheet for deaf students toward learning process. Multiplication is selected due to its ability to represent mathematics subject which will be developed for deaf students. This research uses research and development method $(R \& D)$ with 6 deaf subjects in grade V in special needs education Sri Soedewi Masjchun Sofwan Jambi. This research applies ADDIE model, analysis, design, development, implementation, and evaluation. The data collected are qualitative and quantitative.Qualitative data are collected from media expert validity and learning design, material expert validity, teachers' respond from deaf class. Meanwhile, quantitative data are collected from final test and students' perception on learning media which has been created. Valid students' worksheet is based on questionnaire administered to validator. $79 \%$ of students' responds show positive respond and 83,3\% of learning completion. It shows that mathematics worksheet developed feasible to use in learning process
\end{abstract}

Keywords:Students' worksheet (LKPD), deaf students, multiplication

\begin{abstract}
Abstrak.Penelitian ini bertujuan untuk mendeskripsikan pengembangan LKPD matematika untuk siswa tunarungu dan mengetahui keefektivan LKPD matematika untuk siswa tunarungu terhadap pembelajaran.Materi perkalian dipilih karena dipandang mampu untuk mewakili materi matematika yang akan dikembangkan bagi anak tunarungu. Penelitian ini menggunakan metode Research and Development (R\&D) dengan subjek 6 orang siswa tunarungu kelas V di SLB Negeri Sri Soedewi Masjchun Sofwan Kota Jambi.Penelitian ini menggunakan model pengembangan ADDIE, analisis,desain, pengembangan, pelaksanaan,dan evaluasi.Jenis data yang diambil yaitu data kualitatif dan data kuantitatif. Data kualitatif diperoleh dari hasil angket oleh validator ahli media dan desain pembelajaran, serta ahli materi, dan tanggapan dari guru kelas tunarungu. Sedangkan kuantitatif diperoleh dari hasil belajar siswa respon siswa terhadap media pembelajaran yang telah dibuat. Hasil penelitian diperoleh LKPD yang valid berdasarkan angket yang diberikan kepada validator.Untuk respon siswa diperoleh respon positif dengan hasil persentase sebesar $79 \%$ dan persentase ketuntasan belajar 83,3\%. Hal ini menunjukkan bahwa LKPD matematika yang dikembangkan layak digunakan dalam proses.
\end{abstract}

Kata Kunci:Lembar Kerja Peserta Didik (LKPD), siswa tunarungu, perkalian.

\section{PENDAHULUAN}

Pembelajaran matematika harus terus dimaksimalkan dengan berbagai upaya Sari, Habibi, \& Putri, 2018). Upaya peningkatan kualitas pembelajaran matematika mestilah melintasi semua perbedaan baik gender, latar belakang sosial maupun fisik sekalipun dan termasuklah anak dengan kebutuhan khusus. Anak berkebutuhan khusus adalah anak yang memiliki perbedaan dengan anak-anak pada umumnya. Anak berkebutuhan khusus didefinisikan sebagai anak yang memerlukan pendidikan dan layanan khusus untuk 
mengembangkan potensi kemanusiaan mereka secara sempurna (Hallahan dan Kauffman, 2006: 12). Perbedaan tersebut memiliki nilai lebih atau kurang. Efek perbedaan yang dialami oleh seseorang seringkali mengundang perhatian orang-orang yang ada di sekelilingnya (Efendi, 2008: 2).

Pada anak berkebutuhan khusus dengan golongan tuna pendengaran atau anak tunarungu adalah ketika seseorang mengalami kesulitan mendengar yang berat sehingga mengalami hambatan di dalam memproses informasi bahasa melalui pendengaran, baik memakai atau tidak memakai alat bantu dengar (hearing aid) (Hallahan dan Kauffman, 2006:266).Bagi anak tunarungu, mereka memiliki hambatan dalam menerima pelajaran seperti siswa pada umumnya karena keterbatasan komunikasi penyampaian materi pelajaran secara verbal.

Menurut Kidd, Madsen, dan Lamb (Vesel dan Robillard,2013:362) bahwa ada lima masalah umum yang ditemui pada siswa tunarungu, seperti mengartikan kata yang bermakna ganda, minimnya kosakata, kata yang lebih khusus dalam matematika, singkatan, dan simbol khusus. Efeknya dapat menyebabkan perbedaan signifikan tentang apa yang tidak dapat dan apa yang dapat dilakukan oleh anak tunarungu maupun anak normal.

Sebuah studi dari Wollman (1965) menjelaskan bahwa siswa usia 14 tahun-16 tahun dengan kesulitan pendengaran, menunjukkan penundaan aritmatika rata-rata 2,5 tahun dari siswa lainnya. Keterlambatan dalam prestasi belajar juga dikemukakan oleh (Hess,2015:2) bahwa siswa tunarungu menunjukkan prestasi yang lebih lambat dari siswa dengan tanpa hambatan pendengaran dengan usia yang sama dalam kemampuan akademis, termasuk kemampuan matematika.Dari data tersebut, peneliti menyimpulkan bahwa pada dasarnya setiap anak, baik itu anak berkebutuhan khusus maupun anak normal mengalami problema dalam belajar. Hanya saja problema tersebut ada yang ringan dan ada yang berat sehingga perlu mendapatkan bimbingan khusus.Khususnya untuk mata pelajaran matematika.

Meskipun ada penundaan dalam pembelajaran matematika. Tetapi, intelegensi dari penyandang tunarungu atau kurang pendengaran pada umumnya normal.Variasi intelektual anak tunarungu tidak berbeda dengan variasi anak normal.Ada anak tunarungu yang intelegensinya superior, ada yang rata-rata, ada yang lamban, dan ada juga yang terbelakang menurut Salim dan Sumarsono (1984:14). Keberagaman kemampuan kognitif peserta didik menuntut pemahaman yang baik oleh guru dan fasilitator dalam pembelajaran. Oleh karena itu, guru perlu mengetahui bagaimana peserta didik dalam memahami setiap materi pembelajaran yang disajikan (Kamid,2011:8).

Kelly,et al (2002:20) menyimpulkan bahwa guru perlu diberikan latihan strategi representasional (baik tertulis, maupun grafis). Beberapa tingkat masalah, dan peningkatan kompleksitas pembandingan masalah, dengan berbagai bahasa komparatif.Pagliaro dan Ansell (Lang dan Pagliaro, 2007:450) juga mendiskusikan kemampuan kognitif umum dan pengalaman untuk soal pemecahan masalah sebagai solusi yang memungkinkan untuk siswa tunarungu yang memiliki prestasi yang tidak begitu baik pada pelajaran matematika. Disarankan, guru-guru dapat memasukkan lebih banyak soal pemecahan masalah di dalam pembelajaran mereka sebagai dasar untuk membangun pengetahuan matematika.

Serangkaian perangkat pembelajaran yang harus dipersiapkan seorang guru di kelas antara lain : Rencana Pelaksanaan Pembelajaran (RPP), Lembar Kerja Peserta Didik (LKPD), bahan ajar, dan tes hasil belajar. Bahan ajar menurut Lestari (2013:1) merupakan seperangkat sarana atau alat pembelajaran yang berisikan materi pembelajaran, metode, batasan-batasan, dan cara mengevaluasi yang didesain secara sistematis, menarik, dalam rangka mencapai tujuan yang diharapkan. Bahan ajar beragam jenis, salah satunya adalah LKPD. 
Di antara berbagai perangkat pebelajaran tersebut, peneliti hanya memfokuskan penelitian pada salah satu perangkat, yaitu LKPD.LKPD merupakan suatu perangkat pembelajaran menjadi pendukung buku dalam pencapaian kompetensi dasar siswa. Lembar kerja ini digunakan untuk mengarahkan proses belajar siswa. Materi LKPD yang dikembangkan, dipilih berdasarkan Kurikulum 2013 yang dibuat untuk siswa tunarungu Sekolah Dasar (SD) kelas V semester I dengan materi pokok perkalian.

Meskipun pada level tersebut, pada umumnya siswa tanpa gangguan pendengaran sudah menguasai materi itu. Akan tetapi pada siswa tunarungu berbeda. Hal ini serupa dengan data dari Stanford Achievement Test, yang membuktikan bahwa ketika mereka lulus, 50\% siswa tunarungu dan gangguan pendengaran kelas 4-8 menunjukkan kemampuan di bawah level kelas enam untuk materi hitungan, dan hanya level kelas lima untuk materi pemecahan masalah menurut Traxler (Vesel dan Robillard, 2013:362).

Hasil tersebut juga ditemukan melalui hasil wawancara dengan guru tunarungu kelas $\mathrm{V}$ dan pengamatan peneliti menemukan bahwa siswa kelas $\mathrm{V}$ masih kesulitan dalam perkalian karena siswa berusaha menghapal perkalian.Ketika siswa tidak mengingat hapalannya, siswa tersebut tidak mampu menjawab soal. Buku yang dipakai oleh siswa kelas V adalah buku kurikulum 2013, konten materi untuk siswa tunarungu dikemas dalam bentuk tematik.Akan tetapi, buku tersebut belum menunjang untuk mengarahkan siswa memahami materi perkalian.Sehingga menurut peneliti, siswa perlu diberikan bahan ajar penunjang khusus berupa LKPD. Pengembangan LKPD ini tentu saja akan berbeda dengan LKPD siswa tanpa gangguan pendengaran. LKPD yang dikembangkan disesuaikan dengan psikologi dan taraf kemampuan siswa tunarungu. Di dalam LKPD ini akan mempergunakan perintah-perintah dan bahasa yang mudah dipahami anak tunarungu. Sebab siswa tunarungu telah ditemukan bahwa terkadang lebih fokus terhadap kata-kata dan ide ketika membaca teks daripada memahami keseluruhan teks. Termasuk hubungan antar kata-kata dan ide (Kelly et al, 2002:121).

Selain itu, hal ini juga disebabkan oleh kekeliruan seorang tester dalam menyampaikan perintah tes kepada anak tunarungu berdampak pada kesesatan interpretasi terhadap kondisi anak tunarungu yang sebenarnya.Sehingga menurut peneliti di dalam LKPD perlu diberikan contoh-contoh pengerjaan dan penyelesaian. LKPD dapat mendorong peserta didik untuk mengolah sendiri bahan yang dipelajari. Kegiatan belajar yang menggunanakan LKPD memberikan kesempatan penuh kepada peserta didik untuk mengungkapkan kemampuan dan keterampilan, didorong, dan dibimbing berbuat sendiri untuk mengembangkan proses berpikirnya. Dengan menggunakan LKPD, anak tunarungu dapat belajar lebih mandiri sesuai dengan petunjuk yang ada.

Pengembangan LKPD untuk anak tunarungu pernah diteliti oleh Purwaningsih dan Sulisworo (2015) pada pokok bahasan suhu dan termometer dilihat dari aspek isi, penyajian, bahasa, dan gambar. Hasilnya, bahwa kelayakan ditinjau dari validasi ahli materi, ahli media, guru mata pelajaran dan guru pendamping khusus serta siswa berturutturut sebesar 92,65\%, 78,75\%, 96,67\%, dan 86\%. Hal tersebut menunjukkan bahwa LKS fisika yang dikembangkan untuk anak tunarungu layak digunakan dalam proses pembelajaran.

Berdasarkan permasalahan yang dialami oleh siswa tunarungu serta beberapa penelitian sebelumnya dengan penggunaan LKPD kepada siswa tunarungu.Maka dianggap perlu dan penting untuk melakukan kajian mendalam terhadap penggunaan LKPD dengan materi perkalian kepada siswa tunarungu.Sehingga rumusan masalah yang dikaji dalam penelitian ini adalah bagaimana mengembangkan LKPD matematika siswa tunarungu?Bagaimana efektivitas LKPD matematika untuk siswa tunarungu? 


\section{METODE}

Pada penelitian pengembangan Lembar Kerja Peserta Didik (LKPD) ini, menggunakan metode pengembangan Research and Development (R\&D). Research and Development merupakan penelitian yang digunakan untuk menghasilkan produk tertentu untuk menguji keefektifan produk tersebut. Model pengembangan yang digunakan adalah model ADDIE. Menurut Branch (2009:2) ADDIE adalah singkatan dari analyze, design, develop, implement, dan evaluate. Konsep ADDIE diterapkan dalam membangun pembelajaran berbasis kinerja.Model ini dipilih karena lebih prosedural dan bersifat deskriptif.Menunjukkan langkahlangkah yang jelas dan cermat untuk menghasilkan produk.

Pada tahap analisis dilakukan analisis kebutuhan dan karakteristik siswa, analisis kurikulum, analisis materi, dan analisis lingkungan kerja. Selanjutnya tahap design, yang dilakukan yaitu menentukan jadwal pengembangan, menentukan tim pengembangan, spesifikasi produk yang akan dikembangkan (menghasilkan instrumen penelitian), struktur dan konfigurasi materi yang akan dikembangkan, dan membuat draft /prototipe produk. Tahap berikutnya adalah pengembangan.produk. Dikembangkan berdasarkan saran yang diberikan atau divalidasi oleh ahli media dan ahli materi. Setelah produk direvisi sesuai sarandari tim ahli validasi, selanjutnya dilakukan evaluasi formatif.

Tabel 1. Pengembangan LKPD untuk siswa tunarungu

\begin{tabular}{|c|c|c|c|}
\hline Variabel & Indikator & Karakteristik Bahan Ajar & $\begin{array}{l}\text { Deskripsi LKPD untuk siswa } \\
\text { tunarungu }\end{array}$ \\
\hline \multirow[t]{3}{*}{$\begin{array}{l}\text { Penggunaan bahan ajar } \\
\text { matematika } \\
\text { menggunakanLKPDuntuk } \\
\text { siswa tunarungu }\end{array}$} & Dikdaktik & $\begin{array}{l}\text { Tekanan pada proses untuk } \\
\text { menemukan konsep- } \\
\text { konsep sehingga LKPD } \\
\text { disini berfungsi sebagai } \\
\text { petunjuk bagi peserta didik } \\
\text { untuk mencari tahu }\end{array}$ & $\begin{array}{ll}\text { - } & \text { Memperbanyak contoh } \\
\text { soal dan penyelesaian } \\
\text { sehingga siswa dapat } \\
\text { menemukan konsep. } \\
\text { - Sesuai dengan standard si } \\
\text { yang memenuhi KD untuk } \\
\text { siswa tunarungu kelas V }\end{array}$ \\
\hline & Konstruksi & $\begin{array}{l}\text { Menggunakan bahasa yang } \\
\text { sesuai dengan tingkat } \\
\text { kedewasaan peserta didik }\end{array}$ & $\begin{array}{l}\text { Dsisajikan dalam bahasa } \\
\text { yang lebih sederhana. } \\
\text { Terdiri dari 5-8 suku kata. }\end{array}$ \\
\hline & Grafis & $\begin{array}{l}\text { Gambar, menarik dan } \\
\text { dapat menyampaikan } \\
\text { pesan/isi }\end{array}$ & $\begin{array}{ll}\text { - } & \text { Ada visualisasi konsep } \\
\text { berupa gambar } & \\
\text { - } & \text { Ilustrasi yang berwarna } \\
\text { akan memperjelas konsep } \\
\text { yang dibawakan }\end{array}$ \\
\hline
\end{tabular}

Pada tahap pengembangan juga dilakukan tahap uji coba.Dalam proses kegiatan uji coba, terdapat tiga kali ujicoba, yaitu ujicoba perorangan, kelompok kecil, dan uji coba kelompok besar. Subjek uji coba perorangan adalahsatu orang guru tunarungu.Setelah produk diujicobakan kepada guru tersebut, kemudian guru akan mengisi angket terbuka guna mendapatkan masukan awal terhadap media yang dikembangkan. Selanjutnya, subjek uji coba kelompok kecil terdiri atas 2 siswa. Hasil uji coba kelompok kecil ini dipakai untuk melakukan revisi produk atau rancangan. Setelah direvisi, dilakukan uji coba kelompok besar yang melibatkan subjek 6 siswa.Angket yang digunakan adalah angket tertutup.

Pada tahap implimentasi produk yang telah diuji coba diterapkan dalam situasi nyata dengan pembelajaran yang sesungguhnya.Setelah pembelajaran dilaksanakan diberikan angket persepsi kepada siswa yang merupakan angket tertutup digunakan untuk menilai aspek pada media secara keseluruhan. Serta pada implementasi juga digunakan soal posttest. Tahap evaluasi dilakukan pada setiap tahap pengembangan untuk memperbaiki media 
di setiap tahapnya, evaluasi ini disebut evaluasi formatif. Sehingga diperoleh sebuah produk yang layak untuk digunakan pada proses pembelajaran. Media yang dikatakan efektif apabila sudah mencapai KKM yang ditentukan sekolah dan media dipersepsikan secara positif oleh siswa.

Jenis data yang diambil yaitu data kualitatif dan data kuantitatif. Data kualitatif diperoleh dari hasil validator ahli media, ahli materi, tanggapan dari guru kelas tunarungu, dan hasil angket persepsi siswa terhadap media pembelajaran yang telah dibuat. Sedangkan kuantitatif diperoleh dari hasil belajar siswa melaluipost-test (tes akhir) dan respon siswa. Dalam penelitian ini, instrumen yang digunakan adalah berupa angket dan soal post-test.

Angket terbukaakan diberikan kepada tim ahli desain berupa angket validasi desain pembelajaran dan tim ahli materi berupa angket validasi materi pembelajaran, angket tanggapan uji coba perorangan, tanggapan kelompok kecil dan kelompok besar. Saran dan masukan dari tim ahliberupa data kualitatif yangmenyatakan produk yang dikembangkan layak atau valid. Angket tertutup digunakan pada tahap implementasi yangakan diberikan beberapa jawaban alternatif dengan menggunakan skala penilaian. Post testmerupakan butir tes yang digunakan untuk mengetahui hasil belajar siswa setelah mengikuti kegiatan belajar mengajar.Sebelum melakukan post test, maka disusunlah seperangkat soal-soal tes dalam bentuk soal singkat yang memenuhi indikator kompetensi dasar.

\section{HASIL DAN PEMBAHASAN}

LKPD yang dikembangkan terdiri atas judul, pengantar, materi, dan tugas. Materi yang dikembangkan di dalam LKPD adalah perkalian. Materi dimulai dari perkalian bilangan 1, konsep perkalian, sifat perkalian, melengkapi perkalian, dan operasi bilangan. Karakteristik LKPD ini lebih banyak menggunakan gambar daripada kata-kata untuk membedakan LKPD bagi anak normal dengan anak tunarungu.

Pada materi perkalian bilangan 1, siswa mengamati pola perkalian dari gambar. Gambar yang dibuat adalah gambar yang dekat dan sering dijumpai oleh siswa. Siswa mengamati ada satu tangkai mawar yang berjajar. Kemudian, siswa akan menjumlahkan mawar tersebut. Sehingga didapatlah ada lima mawar dalam satu tangkai. Pada kegiatan ini, siswa telah melakukan operasi perkalian melalui pengamatan pola penjumlahan.

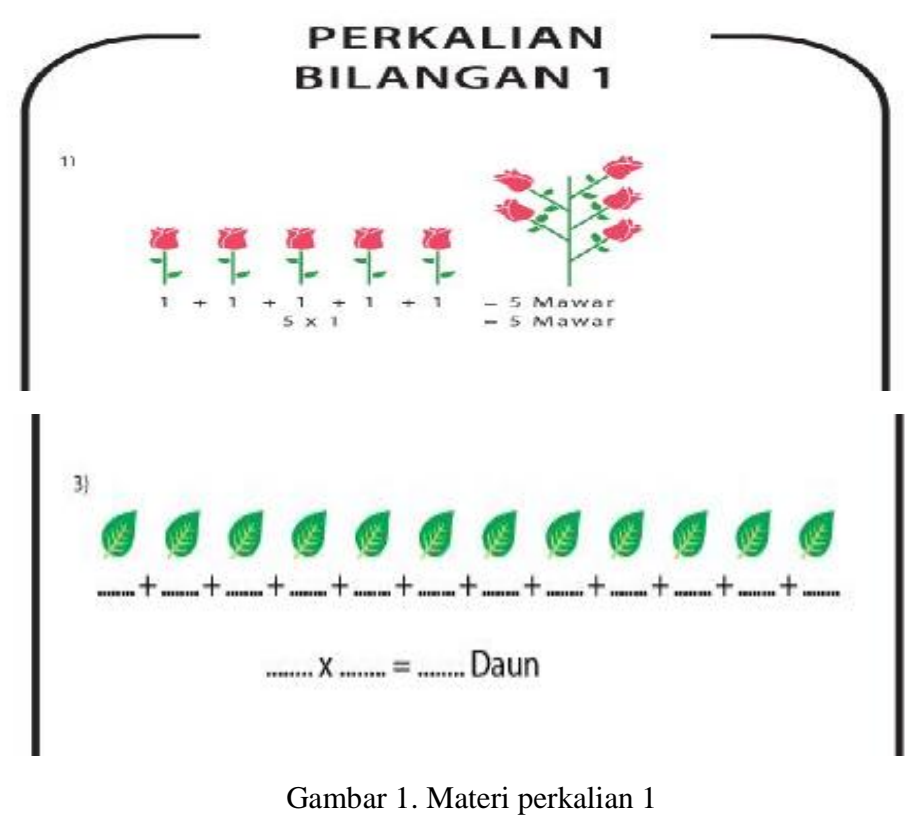

Available online at Journal homepage: ejournal.iainkerinci.ac.id/index.php/edumatika Email: edumatika@iainkerinci.ac.id 
Adapun kinerja yang dilakukan saat siswa belajar menggunakan LKPD, yaitu siswa melakukan tahap mengamati. Diberikan sebuah gambar atau objek sebagai salah satu penyajian permasalahan awal sebagai objek pengamatan siswa. Lalu, diberikan satu contoh masalah melalui gambar yang belum diketahui penyelesaiannya. Sehingga menimbulkan pertanyaan pada diri siswa bagaimana menyelesaikannya. Pada bagian mengolah informasi, siswa diminta untuk menulis kembali hasil yang telah ia peroleh. Kemudian, ketika mengelola informasi tersebut, siswa membuat sebuah kesimpulan dengan bimbingan peneliti. Selanjutnya, peneliti menampilkan lagi beberapa contoh masalah yang lebih rumit terkait perkalian. Pada tahap mengkomunikasikan, peneliti memberi arahan kepada siswa untuk setiap orang menampilkan hasil jawaban mereka. Peneliti juga meminta siswa untuk menyampaikan apa saja yang mereka dapatkan dan mampu mereka kuasai selama kegiatan pembelajaran. Kegiatan ini peneliti dibantu oleh guru tunarungu untuk membantu peneliti dalam menggunakan bahasa isyarat.

Hasil validasi LKPD yang diberikan kepada validator ahli media dan desain pembelajaran menggunakan instrument angket terbuka. Aspek penilaian, yaitu aspek identifikasi masalah pembelajaran, analisis peserta didik, analisis tugas, tujuan pembelajaran, urutan isi pembelajaran, strategi pembelajaran, perancangan pesan pembelajaran, pengembangan pembelajaran, instrumen evaluasi.Aspek tersebut berdasarkan desain pembelajaran Kemp (2007).Adapun saran dari validator ahli media dan desain pembelajaran, yaitu merevisi tujuan pembelajaran yang harus memuat audience, behavior, condition, dan degree. Ada beberapa gambar yang warnanya tidak jelas. Kalimat perintah pada soal belum menggunakan kalimat yang jelas, dan ukuran huruf yang terlalu kecil.

Untuk aspek penilaian ahli materi, yaitu aspek format, isi, dan bahasa. Adapun saran dari ahli materi adalah setiap hasil yang didapatkan ditambahkan unit untuk menjelaskan hasil dari perkalian tersebut. Kekurangan-kekurangan yang telah disarankan telah diperbaiki sebelum diujicobakan. Pada uji coba perorangan, diberikan angket terbuka kepada guru tunarungu. Angket ini terdiri dari 10 item pertanyaan mengenai kelayakan isi, kebahasaan, sajian, dan kegrafisan. Adapun saran yang diberikan, yaitu gunakan gambargambar yang sering dijumpai dan dekat dengan peserta didik, gunakan kalimat perintah yang jelas karena peserta didik tunarungu kesulitan dalam membuat kesimpulan. Hal ini sesuai dengan pendapat Hyde (2014:214) bahwa keterlambatan siswa tunarungu dikarenakan oleh perkembangan dari bentuk bahasa alternatif yang mana adalah bahasa isyarat. Hal tersebut memiliki dampak pada tipe pemahaman yang siswa kembangkan berkaitan dengan konsep matematika.

Selanjutnya, uji coba kelompok kecil. Berdasarkan penilaian angket dan hasil skor yang diperoleh dari pengisian angket tertutup. Maka diperoleh skor pengisian angket dengan skor pengisian 1 orang siswa dalam kategori baik, yaitu 34,02<X $\leq 42,02$ dan 1 orang lainnya diperoleh skor $X>42,06$, yaitu sangat baik. Pada uji coba kelompok besar yang terdiri dari 4 orang. Berdasarkan penilaian responden, produk pembelajaran termasuk dalam kategori "baik" yaitu $34,02<\mathrm{X} \leq 42,02$. Berdasarkan penilaian tersebut, dapat disimpulkan tanggapan siswa tentang LKPD ini menarik dan baik.

Selanjutnya, dilakukan pengisian angket respon yang terdiri dari 10 butir pertanyaan.Angket persepsi siswa kemudian dihitung persentasi untuk setiap kriteria persepsi siswa agar dapat dilihat kelayakan media pembelajaran tersebut.Berdasarkan hasil respon siswa terhadap LKPD matematika untuk siswa tunarungu. LKPD ini mempunyai respon positif yang sangat baik atau positif dari siswa karena memiliki persentase positif yaitu $79,00 \%$ yang masuk kriteria $70 \% \leq \mathrm{RS}<85 \%$ dengan kualitas "positif". 
Tabel 2. Data Hasil Analisis Respon Siswa

\begin{tabular}{|c|c|c|c|c|c|c|c|c|c|}
\hline \multirow{2}{*}{$\begin{array}{c}\text { Aspek } \\
\text { yang } \\
\text { Dinilai }\end{array}$} & \multirow{2}{*}{$\begin{array}{l}\text { Kriteria } \\
\text { Penilaian }\end{array}$} & \multicolumn{5}{|c|}{ Alternatif Penilaian } & \multirow[t]{2}{*}{ Skor } & \multirow[t]{2}{*}{ Persentase } & \multirow[t]{2}{*}{ Kategori } \\
\hline & & 5 & 4 & 3 & 2 & 1 & & & \\
\hline \multirow{3}{*}{$\begin{array}{l}\text { Aspek } \\
\text { Isi }\end{array}$} & 1 & 4 & 1 & 1 & 0 & 0 & 27 & 90 & Positif \\
\hline & 2 & 3 & 1 & 2 & 0 & 0 & 25 & 83,3 & Positif \\
\hline & 3 & 0 & 6 & 0 & 0 & 0 & 24 & 80 & Positif \\
\hline \multirow{3}{*}{$\begin{array}{l}\text { Aspek } \\
\text { Bahsa }\end{array}$} & 4 & 0 & 5 & 1 & 0 & 0 & 23 & 76,67 & Positif \\
\hline & 5 & 2 & 1 & 2 & 1 & 0 & 22 & 73,33 & Positif \\
\hline & 6 & 1 & 2 & 3 & 0 & 0 & 21 & 70 & Positif \\
\hline \multirow{2}{*}{$\begin{array}{l}\text { Aspek } \\
\text { Sajian }\end{array}$} & 7 & 2 & 3 & 0 & 1 & 0 & 22 & 73.33 & Positif \\
\hline & 8 & 0 & 5 & 1 & 0 & 0 & 23 & 76.67 & Positif \\
\hline \multirow{2}{*}{$\begin{array}{l}\text { Aspek } \\
\text { Grafis }\end{array}$} & 9 & 1 & 4 & 1 & 0 & 0 & 24 & 80.00 & Positif \\
\hline & 10 & 2 & 4 & 0 & 0 & 0 & 26 & 86.67 & Positif \\
\hline \multicolumn{7}{|c|}{ Rata-rata } & 24,7 & 79,00 & Positif \\
\hline
\end{tabular}

Dari hasil validasi oleh para ahli, pengisian angket, dan hasil post test. LKPD yang telah dibuat menunjukkan penyajian yang layak, karena variasi penyajian yang menarik dan tidak membosankan. Penggunaan LKPD ini lebih baik, karena LKPD dikemas dengan banyak gambar yang dapat membantu siswa memahami materi pembelajaran. Sebagai akibat dari ketunarunguannya, siswa mengalami gangguan dalam pendengaran yang menyebabkan keterbatasan dalam bahasa. Sehingga komunikasi yang didapat dengan baik melalui visual. LKPD ini didesain berdasarkan kekhususan siswa tunarungu. Sehingga membantu siswa dalam belajar perkalian. Pengembangan LKPD untuk siswa tunarungu jika dilakukan oleh Zahroh dan Poedjiastoeti (2016) mengenai pengembangan LKS berbasis kontekstual pada bahan kimia dalam kehidupan sehari-hari untuk siswa kelas VIII di SMPLB tunarungu.Hasilnya, ditinjau dari kelayakan LKPD dari kriteria isi, kebahasaan, dan penyajian sangat layak digunakan. Hal tersebut ditinjau dari kriteria isi $80 \%-86,66 \%$ dari kriteria bahasa dan $80 \%-93,33 \%$ penyajian. Hasil respon siswa menunjukkan respon positif dengan rentang persentase sebesar $66,66 \%-100 \%$.

\section{SIMPULAN}

Dalam proses mengembangkanLKPD matematika untuk siswa tunarungupada materi perkalian dilakukan dalam beberapa tahapan yaitu analyze(analisis), design(Desain), development (Pengembangan), implement (Pelaksanaan)dan evaluation (Evaluasi). Analisis yang peneliti lakukan adalah analisis karakteristik dan kebutuhan, analisis materi, analisis kurikulum, dan analisis lingkungan kerja. Pada tahap design, peneliti melakukan validasi kepada tim ahli media dan desain pembelajaran serta tim ahli materi. Hasil penelitian menunjukkan bahwa LKPD layak digunaka, kelayakan ditinjau dari aspek kelayakan isi bahasa, sajian, dan grafis. Pada tahap pengembangan, peneliti memberikan angket yang diisi oleh guru yang mengajar di kelas tunarungu. Setelah divalidasi dan dinyatakan layak, LKPD dapat digunakan dan diujicobakan pada siswa.Untuk respon siswa diperoleh respon positif dengan hasil persentase sebesar 79\%. Siswa menilai dari segi tampilan LKPD, materi LKPD, gambar, serta kalimat yang digunakan. Persentase ketuntasan belajar yang diperoleh sebesar 83,3\%. Hal ini menunjukkan bahwa siswa telah mencapai kompetensi dasar dari materi perkalian dengan menggunakan LKPD. Dari hasil post test dan respon siswa, LKPD ini dinyatakan efektiv dalam pembelajaran matematika. 


\section{DAFTAR RUJUKAN}

Branch, Robert. (2009). Instructional Design The ADDIE Approach. USA: Springer

Hallahan, D.P \&Kauffman, J.M. 2006. Exceptional Learners Intorduction for Special Education. Amerika: University of Virginia.

Hess, Laura. (2015). Early Childhood Mathematics for Children Who are Deaf or Hard-ofHearing: Amplifying Opporunities to Develop Foundational Math Skills. Utah State University.

Hyde, Merv. (2014). Languange, Arithmetic Word Problems, and Deaf Students : Linguistic Strategies Used to Solve Task. Mathematics Education Research Journal, vol 13, no 2, hh. 204.

Kamid. (2011). Orientasi Soal Matematika Autis Berdasarkan Wawancara dan Lembar Jawaban. Edumatica,vol 1, no 1, hh. 8.

Kelly. R., Lang H., Mousley, K., Davis, S. (2002). Deaf College Students Comprehension of Realtion Language in Arithmatic Compare Problems. Journal of Deaf Studies and Deaf Education, vol 8, no 2, hh. 20.

Kemp, Ross, Morrison, dan Kalman. (2007). Designing Effective Instruction.USA : Call Wiley.

Lang, H \& Pagliaro, C. (2007). Factor Predicting Recall of Mathematics Terms by Deaf Students: Implications for Teaching. Journal of Deaf Studies and Deaf Education, vol 12, no 4, hh. 450 .

Lestari, Ika. (2013). Pengembangan Bahan Ajar Berbasis Kompetensi Sesuai dengan Kurikulum Tingkat Satuan Pendidikan. Padang : Akademi Permata

Purwaningsih, D.W., \& Sulisworo, D. (2015). Pengembangan lembar kerja siswa (LKS) bagi anak berkebutuhan khusus (tuna rungu) SMK kelas $\mathrm{X}$ pokok bahasan suhu dan termometer. Prosiding Pertemuan Ilmiah XXIX HFI, 248-252.

Salim, M dan Sumarsono,S. (1984). Pendidikan Anak Tunarungu. Jakarta.

Sari, M., Habibi, M., \& Putri, R. (2018). Pengaruh Model Pembelajaran Kooperatif Tipe ThinkPairs-Share Dalam Pembelajaran Matematika Terhadap Kemampuan Pemahaman Konsep Matematis dan Pengembangan Karakter Siswa SMA Kota Sungai Penuh. Edumatika : Jurnal Riset Pendidikan Matematika, 1(1), 7-21.

Vesel, J \& Robillard, T. ( 2013).Teaching Mathematics Vocabulary with an Interactive Signing Math Dictionary.Journal of Research on Technology in Education, vol 45, no 4, hh. 36.

Zahroh, H \& Poediastoeti, S. (2016). Pengembangan Lembar Kerja Siswa (LKS) Berbasis Kontekstual Pada Bahan Kimia dalam Kehidupan Sehari-hari untuk Siswa kelas VIII di SMPLB Tunarungu.Unesa Journal of Chemical Education, vol 5, no 3, hh. 725-731. 